endocarditis 1956-1965: analysis of clinical features and treatment in relation to prognosis and mortality. Br Heart $\mathcal{f} 1969$;32:536-42.

${ }^{6}$ Cherubin CE, Neu HC. Infective endocarditis at the Presbyterian Hospital in New York City from 1938-1967. Am f Med 1971 ;51:83-96.

${ }^{7}$ Kaye D. Changes in the spectrum, diagnosis and management of bacterial and fungal endocarditis. Med Clin North Am 1973;57(4):941-57.

${ }^{8}$ Hayward GW. Infective endocarditis: a changing disease-I, II. Br MedF 1973 ;ii :706-9, 764-6.

9 Smith RH, Radford DJ, Clark RA, Julian DG. Infective endocarditis; a survey of cases in the south-east region of Scotland 1969-72. Thorax 1976;31 :373-9.

10 Schnurr LP, Ball AP, Geddes AM, Gray J, McGhie D. Bacterial endocarditis in England in the 1970 s: a review of 70 patients. $Q \mathcal{F}$ Med 1977; $46: 499-512$.

${ }^{11}$ Lowes JA, Hamer J, Williams G, et al. 10 years of infective endocarditis at St Bartholomew's Hospital : analysis of clinical features and treatment in relation to prognosis and mortality. Lancet $1980 ; \mathrm{i}: 133-6$.

${ }^{12}$ Moulsdale MT, Eykyn SJ, Phillips I. Infective endocarditis, 1970-1979. A study of culture-positive cases in St Thomas's Hospital. $Q \mathcal{F ~ M e d}$ $1980 ; 49: 315-28$

13 Belli J, Waisbren BA. The number of blood cultures necessary to diagnose most cases of bacterial endocarditis. Am F Med Sci 1956;232:284-8.

14 Werner AS, Cobbs C, Kaye D, Hook EW. Studies on the bacteremia of bacterial endocarditis. FAMA $1967 ; 202: 199-203$.

15 Turnier E, Kay JH, Bernstein S, Mendez AM, Zabiate P. Surgical treatment of candida endocarditis. Chest $1975 ; 67: 262-8$.

16 Pesanti EL, Smith IM. Infective endocarditis with negative blood cultures. Am f Med 1979;66:43-50.

17 Masur H, Johnson WD. Prosthetic valve endocarditis. $\mathcal{F}$ Thorac Cardiovasc Surg 1980;80:31-7.

18 Durack DT. Current practice in prevention of bacterial endocarditis. Br Heart $\mathcal{f} 1975 ; 37: 478-81$.

19 Kaplan EL, Anthony BF, Bisno A, et al. Prevention of bacterial endocarditis. Circulation 1977;56:139A-43A.

${ }^{20}$ Oakley CM, Darrell JH. Infective endocarditis. Prescribers' fournal 1980; 20:98-106.

\section{Bakers' asthma}

Interest in occupational asthma has been rekindled in recent years by the description of important new causes such as isocyanates, solder fluxes, and biological washing powders. ${ }^{1}$ Moreover, investigative techniques have been refined, and simpler methods of assessing the efficacy of treatment have been developed, leading to the possibilities that occupational asthma might become a scheduled occupational disease in Britain and that sufferers might receive industrial disablement benefit.

Of the multitude of known causes of occupational asthma, exposure to grains and flour is the one with the longest history and may also be the most common. Roman bakers are known to have worn masks to protect them from the flour, and Ramazzini, the father of occupational medicine, described shortness of breath and urticaria in grain workers. ${ }^{2}$ In the 1930s the allergic basis of such symptoms in millers was shown,${ }^{3}$ while in the 1940s grain and flour dust were recognised to contain many potential allergens from the flour itself to wheat hairs, fungi, and even mites. ${ }^{4}$ Curiously, more recent work has rediscovered the importance of mites in provoking asthma in farmers handling grains. ${ }^{5}$

There are no reliable estimates of the prevalence of asthma among bakers in Britain. Nevertheless, studies in the Federal Republic of Germany have given us some idea of the pattern of sensitisation and of the numbers of people who might claim industrial disablement benefit for bakers' asthma. Herxheimer $^{6}{ }^{7}$ skin tested all bakers' apprentices in West Berlin and found a progressive increase in the number who showed sensitivity to flour up to over $20 \%$ by the fifth year of apprenticeship. Seven per cent developed skin, nasal, or bronchial symptoms, though very few regarded these as more than a nuisance. A more recent study ${ }^{8}$ found symptoms in almost $5 \%$ of apprentices and about $20 \%$ of established bakers - though some of these had taken as long as 32 years to develop symptoms. All these men had rhinitis and most had asthma as well. This study also showed an increasing frequency of positive bronchial provocation tests with acetylcholine with greater length of exposure to flour, suggesting that increased bronchial reactivity may just as well be the result of sensitisation to flour as its cause.

Extrapolation from these figures suggests that there are large numbers of bakers presenting to their doctors with workrelated allergic symptoms. Each year in West Germany about 300 bakers claim industrial injury compensation and about a quarter of these receive it. ${ }^{8}$ In Britain clinical impressions suggest that bakers' asthma is not as common as the German figures imply. Possibly young men leave the trade if they develop troublesome symptoms early, leaving a relatively resistant population. Furthermore, much British baking is carried out by large companies, where control of dust levels is generally good, perhaps reducing sensitisation to a minimum. The addition of occupational asthma to the list of scheduled diseases will allow better estimates to be made of the size of the problem.

Even when bakers become eligible for industrial benefit, however, most will prefer to remain in their trade if their symptoms can be controlled. Prevention of exposureprimarily by reduction of dust levels but also by suitable respirators-remains the cornerstone of management. Occupational asthma also usually responds satisfactorily to standard treatment. Regular inhalation of cromoglycate or beclomethasone, supplemented by a beta-adrenergic aerosol, is usually sufficient to maintain the patient in reasonable health. ${ }^{8}{ }^{9}$ Rhinitis, too, often responds to regular prophylaxis with cromoglycate solution. An appropriate combination of environmental and pharmacological measures should be adequate to keep most victims of bakers' asthma well and at work; and disablement benefit should soon be available to those unfortunate enough not to respond to these measures.

${ }^{1}$ Anonymous. Occupational asthma. $\operatorname{Br}$ Med $\mathcal{f} 1979$;ii :82.

2 Ramazzini B. De morbis artificum diatriba. 1700. Cave W, transl. Chicago: Wright, 1940.

${ }^{3}$ Duke WW. Wheat hairs and dust as a common cause of asthma among workers in wheat flour mills. $7 A M A 1935 ; 105: 957-8$.

4 Jimenez-Diaz C, Lahoz C, Canto G. The allergens of mill dust. Asthma in millers, farmers, and others. Ann Allergy 1947;5:519-25.

5 Ingram CG, Jeffrey IG, Symington IS, Cuthbert OD. Bronchial provocation studies in farmers allergic to storage mites. Lancet 1979; ;i:1330-2.

${ }^{6}$ Herxheimer H. Skin sensitivity to flour in bakers' apprentices. Lancet $1967 ; \mathrm{i}: 83-4$.

${ }^{7}$ Herxheimer H. The skin sensitivity to flour of bakers' apprentices. A final report of a long term investigation. Acta Allergologica $1973 ; 28: 42-9$.

8 Thiel H, Ulmer WT. Bakers' asthma: development and possibility of treatment. Chest $1980 ; 78$, suppl:400-5.

${ }^{9}$ Hendrick DJ, Davies RJ, Pepys J. Bakers' asthma. Clin Allergy 1976;6: 241-50.

\section{Correction}

\section{Management of alcohol withdrawal symptoms}

We regret that in the fourth paragraph of our leading article on the management of alcohol withdrawal symptoms (14 February, p 502) the dosage of chlormethiazole was wrongly given as $500-1500 \mathrm{~g}$ every six hours. This should have read $500-1500 \mathrm{mg}$ every six hours. 